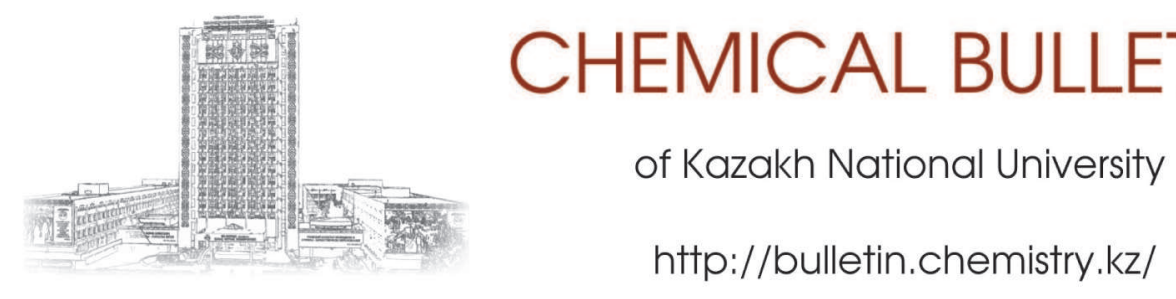

\author{
${ }^{1}$ Mozhayeva D.A., ${ }^{1}$ Zhakupbekova A.A., ${ }^{1}$ Kenessov B.N.*, \\ ${ }^{2}$ Akmoldayeva S.B., ${ }^{3}$ Carlsen L. \\ ${ }^{1}$ Center of Physical Chemical Methods of Research and Analysis, \\ Al-Farabi Kazakh National University, Almaty, Kazakhstan \\ ${ }^{2}$ Almaty Institute of Forensic Expertise, Forensic Expertise Center of the Ministry of Justice \\ of the Republic of Kazakhstan, Almaty, Kazakhstan \\ ${ }^{3}$ Awareness Center, Trekroner, Roskilde, Denmark \\ "E-mail: bkenesov@cfhma.kz
}

\title{
New method for the discovery of adulterated cognacs and brandies based on solid-phase microextraction and gas chromatography - mass spectrometry
}

The article represents new method for discovery of adulterated cognacs and brandies based on solidphase microextraction (SPME) in combination with gas chromatography - mass spectrometry (GC-MS). The work comprised optimization of SPME parameters (extraction temperature and time, concentration of added salt) with subsequent analysis of authentic samples and comparison of the obtained chromatograms using principal component analysis (PCA). According to the obtained results, increase of extraction temperature resulted in an increase of response of the most volatile brandy constituents. To avoid chemical transformations and/or degradation of the samples, the extraction temperature must be limited to $30 \mathrm{C}$. Increase of the extraction time lead to higher total peak area, but longer extraction times ( $>10 \mathrm{~min}$ for $100 \mu \mathrm{m}$ polydimethylsiloxane and $>2 \mathrm{~min}$ for divinylbenzene/Carboxen/polydimethylsiloxane fibers) caused displacement of analytes. Salt addition increased total response of analytes, but caused problems with reproducibility. The developed method was successfully applied for discovery of adulterated samples of brandy, cognac, whisky and whiskey sold in Kazakhstan. The obtained data was analyzed applying principal component analysis (PCA). Five adulterated brandy and whisky samples were discovered and confirmed. The developed method is recommended for application in forensic laboratories.

Key words: gas chromatography; mass spectrometry; cognac; brandy; solid-phase microextraction; principal component analysis; adulteration

1'Можаева Д.А., 'Жакупбекова А.А., 'Кенесов Б.Н., ${ }^{2}$ Акмолдаева С.Б., ${ }^{3}$ Карлсен Л.

1 Физика химиялық зерттеу және талдау орталығы,

Әл-Фараби атындағы Қазақ ұлттық университеті, Алматы, Қазақстан

${ }^{2}$ Алматы қаласыбойынша сот сараптамасы институты,

Қазақстан Республикасы Әділет министрлігінің Сот сараптамасы орталығы, Алматы, Қазақстан

${ }^{3}$ Awareness Center, Trekroner, Роскильде, Дания

Коньяк және брендидің жалған үлгілерін анықтаудың қатты фазалы микроэкстракция мен газды хроматография-масс-спектрометрияға негізделген жаңа әдісі

Мақалада коньяк және брендидің жалған үлгілерін анықтаудың қатты фазалы микроэкстракция (ҚФМЭ) мен газды хроматография-масс-спектрометрияға (ГХ-МС) негізделген жаңа әдісі келтірілген. Жұмыс ҚФМЭ параметрлерін оңтайландырудан, кейінгі реалды үлгілерді талдаудан және алынған 
хроматограммаларды басты компоненттер әдісін қолдану арқылы салыстыру. Алынған нәтижелерге сәйкес, экстракция температурасын жоғарлату бренди құрамындағы ең ұшқыш қосылыстардың жауабының жоғарлауына әкеледі. Үлгілердің химиялық трансформациясын және/немесе деградациясын болдырмау үшін экстракция температурасы $30^{\circ} \mathrm{C}$ шектеледі. Экстракция уақытын жоғарлату шыңның жалпы ауданының жоғарлауына әкеледі, бірақ ұзақ экстракция уақытында (полидиметилсилоксан негізіндегі талшық үшін 10 минуттан ұзақ және дивинил бензол /Карбоксен/ полидметилсилоксан негізіндегі талшық үшін 2 минуттан ұзақ) экстракциялық жабындыдағы бір заттар басқа заттардың орын басады. Тұздың қосылуы анықталатын заттардың жауабын жоғарлатады, бірақ қайталанымдылық тұрғысынан проблемаларды тудырады. Шығарылған әдіс Қазақстанда сатылатын жалған бренди, коньяк және виски үлгілерін анықтауда сәтті қолданылды. Алынған мәліметтер басты компоненттер әдісімен талданылды. Талдау нәтижелерінде бренди және вискидің бес жалған үлгілері анықталып, дәлелденді. Шығарылған әдіс соттық-криминалистикалық зертханаларда қолдануға ұсынылуы мүмкін.

Түйін сөздер: газдық хромотография, масс-спектрометрия, коньяк, бренди, қатты фазалық микроэкстракция, басты компоненттер әдісі, жалған үлгі.

'Можаева Д.А., 'Жакупбекова А.А., 'Кенесов Б.Н., ${ }^{2}$ Акмолдаева С.Б., ${ }^{3}$ Карлсен Л.

${ }^{1}$ Центр физико-химических методов исследования и анализа,

Казахский национальный университет им. аль-Фараби, г. Алматы, Казахстан

2 Институт судебной экспертизы по городу Алматы, Центр судебной экспертизы

Министерства юстиции Республики Казахстан, г. Алматы, Казахстан

${ }^{3}$ Awareness Center, Trekroner, г. Роскильде, Дания

Новый метод выявления поддельных коньяков и бренди
на основе твердофазной микроэкстракции
и газовой хроматографии - масс-спектрометрии

В статье представлен новый метод выявления поддельных коньяков и бренди, основанный на твердофазной микроэкстракции (ТФМЭ) и газовой хроматографии - масс-спектрометрии (ГХ-МС). Работа включала оптимизацию параметров ТФМЭ (температура и время экстракции, концентрация соли) с последующим анализом реальных образцов и сравнением полученных хроматограмм с использованием метода главных компонент. Согласно полученным результатам, увеличение температуры экстракции приводит к увеличению отклика наиболее летучих соединений, содержащихся в бренди. Для предотвращения химической трансформации и/или деградации образцов температура экстракции должна быть ограничена $30^{\circ} \mathrm{C}$. Увеличение времени экстракции приводит к увеличению общей площади пика, но более длительная экстракция (>10 мин для волокна на основе полидиметилсилоксана и >2 мин для волокна на основе дивинилбензола/Карбоксена/полидметилсилоксана) приводит к вытеснению из экстракционного покрытия одних аналитов другими. Добавка соли позволяет увеличить отклик аналитов, но вызывает проблемы с воспроизводимостью. Разработанный метод был успешно применен для выявления поддельных образцов бренди, коньяка и виски, реализуемых в Казахстане. Полученные данные анализировали методом главных компонент. По результатам анализа были выявлены и подтверждены пять поддельных образцов бренди и виски. Разработанный метод может быть рекомендован для применения в судебно-криминалистических лабораториях.

Ключевые слова: газовая хроматография; масс-спектрометрия; коньяк; бренди; твердофазная микроэкстракция; метод главных компонент; подделка.

\section{Introduction}

The problem of adulteration of alcoholic beverages is widespread in Kazakhstan and other former USSR countries. However, hundreds of cases of adulteration are also reported by mass media all around the world. Thus, in May of 2013, Czech police confiscated more than million liters of illegal alcohol [1].

Adulteration of cognac, whisky and brandy is very popular due to the relative ease of component substitution, high prices of famous brands and popularity among customers. Cognac, as any alcoholic beverage can be adulterated by partial or complete replacement of cognac spirit (distilled from fermented grapes) with food alcohol or technical (commercial) alcohol, as well as dilution or full replacement with colored water solutions. The special means and methods of falsification include replacement with a drink with a short retention (aging in barrels) period, replacement with an alcoholic extract of tea to simulate, colorization 
of cognac spirit, replacement by an alcohol extract from vegetable raw materials having a high content of tanning agents (oak chips, walnut shells, etc.). Most often, adulteration of cognac, whisky and brandy is done by dilution with water, tea or alcohol-based liquids: vodka, starka (rye vodka), chacha (grape vodka), wine, etc.

Adulteration of alcoholic drinks has negative economic effects as well as potentially being damaging to human health. In addition to direct profit losses, manufacturers of original products lose potential customers due to quality concerns caused by consumption of adulterated alcohols. Human health consequences can vary from chronic to acute toxic action by chemicals present in the adulterated samples. According to the data, the most fatal cases are caused by consumption of adulterated vodkas due to methanol poisoning. For example, in 2012, 26 people died in Czech Republic due to the poisoning by alcohol [2]. Quality control on the "garage" manufactures is in most cases nonexisting. Such manufacturers do not care about the quality and safety of their products as they sell them under different brands.

In most countries, adulteration of alcohols is considered as a serious crime. However, this problem is difficult to avoid completely. It is well known that the market of adulterated alcohols grows if the price of original alcohol increases due to the higher demand and potential profits. Hence, the problem is particularly widespread in developing countries where people cannot afford original products.

The key instruments to fight adulteration are law enforcement agencies, e.g. police and forensic laboratories, and courts. Their work includes:

- screening of the market of alcohols for adulterated samples;

- collection of evidence to prove the fact of adulteration;

- discovering and convicting individuals or companies responsible for adulteration.

Appropriate legislation can be efficient to minimize alcohol adulteration. However, it requires scientific data and background and requires time to implement.

The efficiency of law enforcement against adulteration depends on chemical analysis that allows collection of data on chemical composition and further investigations. Without chemical analyses, it is very difficult to prove adulteration. Such analyses are typically performed in specialized forensic or general analytical laboratories. For acceptance of data by the court, such laboratories may need to be certified or accredited.
When the goal is to confirm adulteration, there are two main approaches utilized both requiring the involvement of skilled analytical chemical expertise: 1 . detection of known chemical markers of adulteration and 2. determination of the concentrations of individual compounds and/ or their ratios. Statistical methods (e.g., principal component or cluster analyses) are in this respect efficient tools when dealing with large number of target compounds.

Efficient methods for analysis of alcoholic beverages are based on the physical chemical methods such as gas chromatography (GC) [3-4], liquid chromatography (LC) [5-6], spectroscopic methods like ultraviolet (UV), infrared (IR) [7-8] or nuclear magnetic resonance (NMR), and mass spectrometry [9]. The most efficient methods are based on hyphenated techniques like chromatography (GC or LC) - mass spectrometry (MS), because they provide separation efficiency, selectivity as well as possibility for identification. Sensor-based devices are very good alternative for quick and on-site discovery of adulterated alcoholic samples, but their results should be confirmed by more specific analytical methods before reaching a court.

In Kazakhstan, for quality control of alcoholic beverages, most laboratories use standard GOST methods. These methods are based on determination of the main physical and organoleptic parameters, and analysis of the content of some chemicals, e.g., ethanol, alcohols, aldehydes and esters. In the forensic practice, two methods based on GC-FID [3-4] are the most often used. However, this method is based on direct sample injection and has poor sensitivity because injection of water is undesirable for GC based analyses.

Savchuk et al. [10] conducted a study to identify the compounds in brandy to confirm adulteration. Using headspace GC-MS and LC, authors has found that the presence of excessive concentrations of 2-butanol, acetic acid, ethyl acetate, acetaldehyde, ethyl lactate, methane acid, fatty acids ethyl esters, diacetals, acetoin and acetals may be the evidence of adulteration.

Despite the large number of methods available in the literature, application of most of these methods for disclosing adulteration has not been reported. Another problem is caused by the fact that providing sufficient evidence for adulteration is typically not possible applying only a single method.

According to the publications, highest number of analytes in alcoholic beverages can be detected by GC-MS in combination with headspace (HS) solid- 
phase microextraction (SPME) [11]. HS SPME is very popular sampling and sample preparation technique based on the extraction of the target analytes from gaseous phase above the sample onto a thin polymer coating. Its main advantages include low cost of analysis, simplicity of use and ease of automation.

SPME was used for fingerprinting of brandies [12], wines [11], rums [13], whiskies [14] and cachaca [15]. As reported by Rodriguez et al. [16], fiber coatings based on Carboxen (CAR) / polydimethylsiloxane (PDMS) and divinylbenzene (DVB)/CAR/PDMS appeared as the most efficient for extraction taking into account total peak areas of analytes. Camara et al. [14] reported that fiber based on Carbowax $(\mathrm{CW}) / \mathrm{DVB}$ provided the highest extraction efficiency of all volatile organic compounds (VOCs) excluding the most abundant esters. Rodriguez et al. [16] demonstrated that, for wine and beer samples, the maximum total peak area was observed at extraction temperature $30^{\circ} \mathrm{C}$. For whisky samples, optimal temperature was $40^{\circ} \mathrm{C}$ [16]. Maximum response of analytes was normally observed at extraction time $>60 \mathrm{~min}[14 ; 16]$.

It was shown that ethanol concentration significantly affects SPME efficiency. Thus, the highest response was observed at ethanol concentration of $12 \%$ [13]. For some analytes, it was in the range of $10-20 \%$ [17]. Addition of sodium chloride was always used to promote analyte transfer from sample to headspace [11-17]. During method optimizations, authors mostly focused on selectivity and sensitivity rather than other very important specifications such as reproducibility, response linearity and reliability. These specifications appear of high importance in order to differentiate between adulterated and original samples as well as finding the origin of the product.

The objective of the present study was to optimize the SPME-GC-MS method for detection of VOCs in Kazakh brandies and disclosing possible adulterated brandy samples. The work comprised optimization of SPME parameters and application of the method for analysis of the authentic samples. Optimization was focused on obtaining reproducible and reliable results at sufficient sensitivity and simplicity.

\section{Experimental part}

\section{Samples}

The method development was done using threestar "Kazakhstan" brandy ("Bacchus" OJSC, Almaty, Kazakhstan) [18] purchased at the official shop of the manufacturer. This brandy was selected because it apparently is the most popular in Kazakhstan. In
Kazakhstan, this brandy is traditionally called "коньяк" (pronounced as "cognac"). However, according to the international legislation [19], only the French cognac regions has a right to produce alcoholic beverages under the name "cognac". However, the technology for production of Kazakh "коньяк" is very close to the technology for production of original cognac. Further in the paper, such samples will be denoted "Kazakh brandies" or brandies.

To decrease ethanol concentration to the optimal value around $12 \%$ [13], all experimental samples were prepared by mixing $2.00 \mathrm{~mL}$ of the alcoholic beverage sample with $4.00 \mathrm{~mL}$ of distilled water in $20 \mathrm{~mL}$ vials (CTC Analytics, Switzerland). After preparation, samples were located onto a 32-position tray for $10 / 20 \mathrm{~mL}$ vials of Combi Pal autosampler and analyzed by GC-MS.

\section{Instrumentation}

All experiments were conducted on a $6890 \mathrm{~N} / 5973 \mathrm{~N}$ GC-MS system (Agilent, USA) equipped with two split/splitless inlets and flameionization detector (FID). SPME was conducted using Combi-PAL autosampler (CTC Analytics, Switzerland) installed on the GC-MS system and equipped with temperature-controlled agitator and fiber conditioning station. Desorption of the extracted compounds from the fiber coating was conducted in the $\mathrm{GC}$ inlet at $240^{\circ} \mathrm{C}$ equipped with $0.75 \mathrm{~mm}$ i.d. SPME liner (Supelco, USA). The oven temperature was programmed from $40^{\circ} \mathrm{C}$ (held for $2 \mathrm{~min}$ ) to $180^{\circ} \mathrm{C}$ at a ramp $2^{\circ} \mathrm{C} / \mathrm{min}$, followed by a $10^{\circ} \mathrm{C} / \mathrm{min}$ ramp to $280^{\circ} \mathrm{C}$ (held for $20 \mathrm{~min}$ ).

Separation prior to MS detection was done on a $30 \mathrm{~m}$ x $0.25 \mathrm{~mm}$ DB-35MS (0.25 $\mu \mathrm{m}$ film) column at constant flow rate of helium $(99.995 \%$ purity, Orenburg-Tehgas, Russia) equal to $1 \mathrm{~mL} / \mathrm{min}$. MS detection was performed by scanning ions in the range 34-300 amu. Temperatures of interface, ion source and quadrupole were 240,230 and $150^{\circ} \mathrm{C}$, respectively.

Separation prior to FID was performed using a DB-1MS $30 \mathrm{~m} \times 0.25 \mathrm{~mm}, 0.25 \mu \mathrm{m}$ i.d. capillary column at a constant flow rate of helium equal to 1.5 $\mathrm{mL} / \mathrm{min}$. Detection was carried out at temperature of $250^{\circ} \mathrm{C}$. Flow rates of hydrogen, air and makeup gas (helium) were set to 30,300 and $15 \mathrm{~mL} / \mathrm{min}$, respectively. Total time of the analysis was 102 minutes.

In the study, two SPME fibers (Supelco, USA) were used: $100 \mu \mathrm{m}$ PDMS and DVB/CAR/PDMS.

Characterization of the experimental sample used for method optimization

The sample of "Kazakhstan" brandy ("Bacchus" OJSC, Almaty, Kazakhstan) was analyzed using two different approaches: 
1) extraction time $30 \mathrm{sec}$, temperature $30^{\circ} \mathrm{C}$, without addition of salt;

2) extraction time $30 \mathrm{~min}$, temperature $50^{\circ} \mathrm{C}$, with addition of $1.7 \mathrm{~g}$ desiccated $\mathrm{NaCl}$ (chemically pure, LaborPharma, Kazakhstan).

Extraction was conducted using DVB/CAR/ PDMS fiber coating that previously has been proven to be selective to a wide range of VOCs present in alcoholic beverages [16]. Pre-incubation time was set to $5 \mathrm{~min}$. Longer extraction times lead to an excessive loading of the fiber coating and a significant overload of the MS detector causing a rapid reduction of the MS electron multiplier lifetime. To overcome this problem when analyzing the samples using a 30 min extraction time, the MS detector was switched off during the time periods of elution of the abundant peaks (esters) using a special option in the software. Identification of peaks was performed using NIST' 08 and Wiley 7 th edition MS libraries.
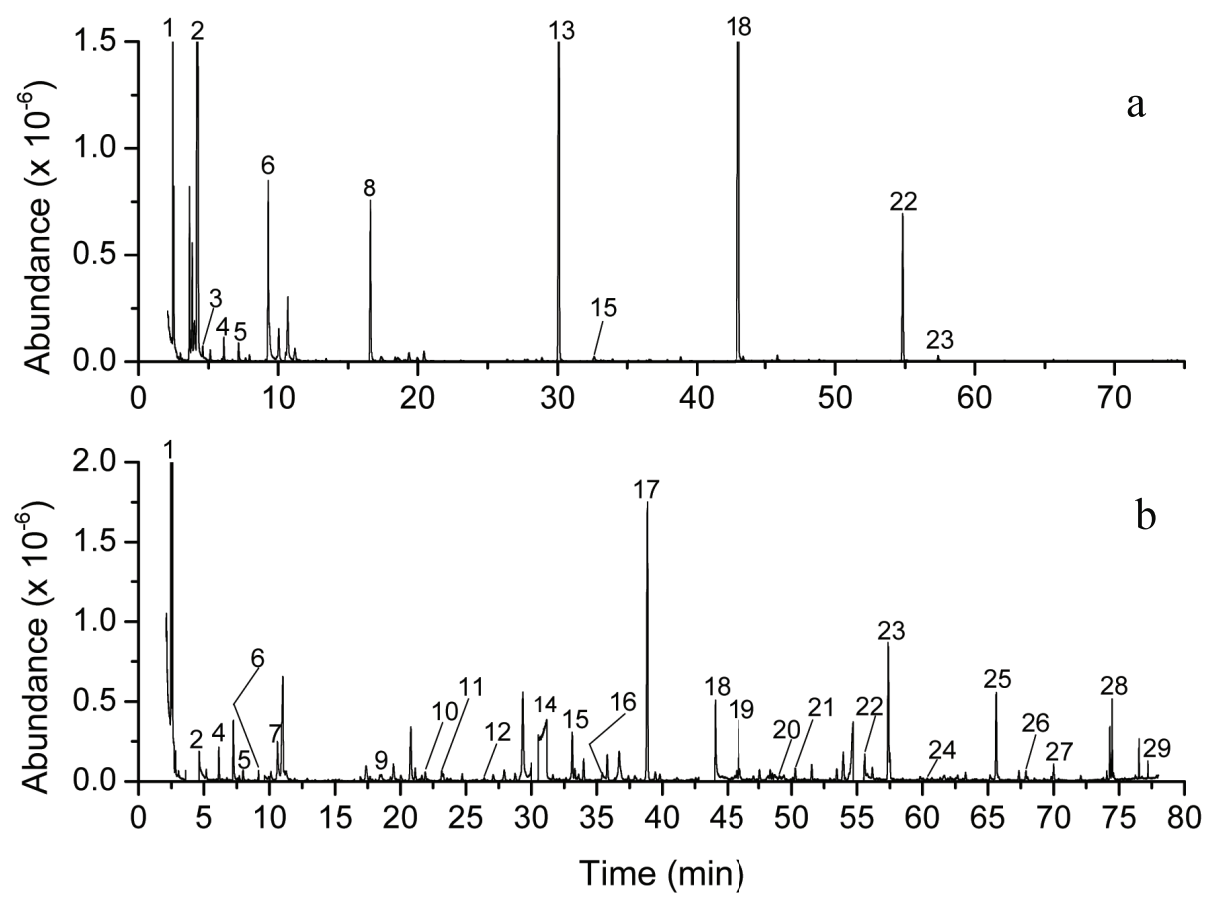

Figure 1 - Chromatograms of "Kazakhstan" brandy ("Bacchus" OJSC, Almaty, Kazakhstan) obtained by SPME-GC-MS using DVB/CAR/PDMS fiber and two different extraction condition: (a) - extraction time $30 \mathrm{sec}$, temperature $30^{\circ} \mathrm{C}$, without addition of salt; (b) - extraction time 30 min, temperature $50^{\circ} \mathrm{C}$, with addition of $1.7 \mathrm{~g} \mathrm{NaCl}$.

From the obtained chromatograms (Figure 1), 49 compounds were identified (Table 1). These compounds mainly included aliphatic and aromatic alcohols, esters, aldehydes and ketones. Most of the detected compounds are known constituents of cognac [10], brandy [10], whisky [14], rum [13], wine [11] and other alcoholic beverages [16-17].

For discovery of adulterated samples, the ratio between these compounds may be important. Some samples may contain chemical markers of origin, e.g., beta-damascenone. If these compounds are volatile and have sufficient concentration, they will be detected by SPME-GC-MS method.

The chemical composition of Kazakh brandy appears to be rather complex. Some of the detected compounds are unstable under certain conditions. To provide the reliability and reproducibility of the developed method, the chemical composition of the samples should not be affected during the sample preparation procedure. Hence, for the method optimization, peak areas of the most intensive peaks were considered: ethyl acetate, isoamyl alcohol, ethyl hexanoate, ethyl octanoate, ethyl decanoate, ethyl dodecanoate, ethyl tetradecanoate, ethyl hexadecanoate and furfural.

Optimization of extraction temperature

Prepared brandy samples were extracted at 30, 45,60 and $70^{\circ} \mathrm{C}$, respectively, using DVB/CAR/ PDMS fiber. To avoid MS detector overload at high temperature, extraction time was set to 15 seconds. Pre- 
incubation time was $15 \mathrm{~min}$. Selection of the minimum extraction temperature was limited by the minimum adjustable temperature in the agitator of the autosampler. The choice of the maximum extraction temperature was due to the fact that for $\mathrm{T}>70^{\circ} \mathrm{C}$, vapor pressure of ethanol rapidly increases. Ethanol may thus occupy all adsorption sites at the coating whereby the extraction of other compounds may be significantly slowed down.

Table 1 - Compounds reliably identified in the studied sample of "Kazakhstan" brandy ("Bacchus" OJSC, Almaty, Kazakhstan)

\begin{tabular}{|c|c|c|c|c|}
\hline \# & Compound & RT (min) & CAS No. & Significant ions, $\mathrm{m} / \mathrm{z}$ (relative abundance, $\%$ ) \\
\hline 1 & Acetic acid & 2.37 & $64-19-7$ & $60(85)$ \\
\hline 2 & Ethyl acetate & 2.4 & $141-78-6$ & $88(7) ; 61(18)$ \\
\hline 3 & 2-Methyl-1-propanol & 2.5 & $78-83-1$ & $41(56) ; 74(12)$ \\
\hline 4 & Diethoxymethane & 2.8 & $462-95-3$ & $59(100) ; 103(68)$ \\
\hline 5 & 2-Methyl butanal & 3.1 & $96-17-3$ & $86(17)$ \\
\hline 6 & Ethyl propanoate & 3.7 & $105-37-3$ & $102(16)$ \\
\hline 7 & Isoamyl alcohol & 4.23 & $123-51-3$ & $55(100) ; 70(77)$ \\
\hline 8 & Ethyl isobutyrate & 4.5 & $97-62-1$ & $116(22) ; 88(18)$ \\
\hline 9 & 1-Butanol-3-methyl formate & 5.6 & $110-45-2$ & $55(100) ; 70(60) ; 41(33)$ \\
\hline 10 & Ethyl butanoate & 6.1 & $105-54-4$ & $88(61) ; 60(21)$ \\
\hline 11 & Ethyl 2-hydroxypropanoate & 7.3 & $97-64-3$ & $45(100) ; 75(11)$ \\
\hline 12 & 2-Methyl ethylbutanoate & 7.6 & $7452-79-1$ & $102(95) ; 74(26)$ \\
\hline 13 & Ethyl 3-methylbutyrate & 7.9 & $108-64-5$ & $88(100) ; 60(40)$ \\
\hline 14 & 1-Hexanol & 9.1 & $111-27-3$ & $56(100) ; 55(49)$ \\
\hline 15 & 3-Methylbutyl acetate & 9.3 & $123-92-2$ & $70(78) ; 87(18)$ \\
\hline 16 & Furfural & 10.6 & $98-01-1$ & $96(100) ; 39(31)$ \\
\hline 17 & Ethyl hexanoate & 16.6 & $123-66-0$ & $88(100) ; 99(58)$ \\
\hline 18 & Benzaldehyde & 18.5 & $100-52-7$ & $105(100) ; 106(84)$ \\
\hline 19 & Ethyl 2-hydroxy-4-methylpentanoate & 21.1 & $10348-47-7$ & $69(100) ; 87(67)$ \\
\hline 20 & $1-$ Octanol & 21.6 & $111-87-5$ & 55 (100); 41 (94); $56(89)$ \\
\hline 21 & Isoamyl lactate & 21.9 & $19329-89-6$ & $45(100) ; 70(54)$ \\
\hline 22 & 2-Nonanol & 23.1 & $628-99-9$ & $45(100) ; 69(25)$ \\
\hline 23 & Acetophenone & 26.4 & $98-86-2$ & $105(100) ; 77(73) ; 120(27)$ \\
\hline 24 & Phenylethyl alcohol & 29.3 & $60-12-8$ & $91(100) ; 92(56) ; 122(28)$ \\
\hline 25 & Ethyl octanoate & 30.1 & $106-32-1$ & $88(100) ; 101(38) ; 127(30)$ \\
\hline 26 & Octanoic acid & 31.3 & $124-07-2$ & $60(100)$ \\
\hline 27 & 3-Ethyl benzaldehyde & 32.6 & $34246-54-3$ & $105(100) ; 122(62) ; 134(60)$ \\
\hline 28 & Ethyl succinate & 33.1 & $123-25-1$ & $101(100) ; 129(67)$ \\
\hline 29 & Methyl salicilate & 33.9 & $119-36-8$ & $120(100) ; 92(48)$ \\
\hline 30 & Decanol & 35.4 & $112-30-1$ & $55(70) ; 70(67)$ \\
\hline 31 & 2-Phenyl acetate & 38.8 & $103-45-7$ & $104(100) ; 91(16)$ \\
\hline 32 & Ethyl decanoate & 43.05 & $110-38-3$ & $88(100) ; 101(42)$ \\
\hline 33 & Ethyl 9-decenoate & 43.4 & $67233-91-4$ & $70(63) ; 55(58)$ \\
\hline 34 & 5-Ethyl-2-methyloctane & 44.9 & $62016-18-6$ & $57(100)$ \\
\hline 35 & Octanoic acid, 3-methylbutyl ester & 45.8 & $2035-99-6$ & $70(100) ; 127(30)$ \\
\hline 36 & 1-(2,5-Dimethylphenyl) ethanone & 48.9 & $2142-73-6$ & $133(100) ; 148(23)$ \\
\hline 37 & Isobutyl decanoate & 51.5 & $30673-38-2$ & $155(100) ; 56(81)$ \\
\hline 38 & $\begin{array}{l}\text { 4-Hexyl-2,5-dihydro-2,5-dioxo-3- } \\
\text { furanacetic acid }\end{array}$ & 53.4 & $39212-21-0$ & 126 (100); $98(24)$ \\
\hline 39 & D-Nerolidol & 53.9 & $142-50-7$ & $69(100) ; 93(69)$ \\
\hline 40 & Ethyl dodecanoate & 54.8 & $106-33-2$ & $88(100) ; 101(47)$ \\
\hline 41 & 3-Methyl butyl decanoate & 57.3 & $2306-91-4$ & $70(100) ; 155(22)$ \\
\hline 42 & 3, 7, 11-Trimethyl-6,10-dodecadien-1-ol & 61.6 & $20576-54-9$ & $69(100) ; 81(65)$ \\
\hline 43 & Ethyl tetradecanoate & 65.6 & $124-06-1$ & $88(100) ; 101(55)$ \\
\hline 44 & $\begin{array}{l}\text { 3,7,11,15-Tetramethyl-6,10,14- } \\
\text { hexadecatrien-1-ol }\end{array}$ & 67.3 & $36237-66-8$ & $81(100) ; 69(98)$ \\
\hline 45 & Isoamyl laurate & 67.8 & $6309-51-9$ & $70(100) ; 55(15)$ \\
\hline
\end{tabular}


Continuation of table 1

\begin{tabular}{|c|l|c|c|c|}
\hline$\#$ & \multicolumn{1}{|c|}{ Compound } & RT $(\mathrm{min})$ & CAS No. & Significant ions, $\mathrm{m} / \mathrm{z}$ (relative abundance, $\%$ ) \\
\hline 46 & Farnesol acetate & 70.01 & $4128-17-0$ & $69(100) ; 93(38)$ \\
\hline 47 & Diisobuthyl phthalate & 74.0 & $84-69-5$ & $149(100) ; 150(0.91)$ \\
\hline 48 & Ethyl 9-hexadecenoate & 74.3 & $54546-22-4$ & $55(100) ; 69(83)$ \\
\hline 49 & Ethyl hexadecanoate & 74.5 & $628-97-7$ & $88(100) ; 101(58)$ \\
\hline
\end{tabular}

Optimization of extraction time

Prepared brandy samples were extracted at $30^{\circ} \mathrm{C}$ for $0.5 ; 1.0 ; 2.0 ; 5.0 ; 10.0 ; 20.0 ; 30.0 ; 60.0$ and 100 min. Pre-incubation time was $5 \mathrm{~min}$. The experiment was conducted using two different fibers: $100 \mu \mathrm{m}$ PDMS and DVB/CAR/PDMS.

In this experiment, flame ionization detector was used instead of mass selective detector due to its better linearity at higher analyte concentrations. Utilization of MS detector in the preliminary experiment led to a strong detector overload. Obtained chromatograms were integrated by calculating the sum of areas of all peaks having RT $>8$ min, and areas of the most abundant peaks.

\section{Optimization of salt addition}

The mass of $\mathrm{NaCl}$ varied during the experiment to $0.25,0.75,1.25$ and $1.75 \mathrm{~g}$. The highest value corresponded to $\mathrm{NaCl}$ saturation in $12 \%$ ethanol solution. Extraction was done by DVB/CAR/PDMS fiber at $30^{\circ} \mathrm{C}$ during $30 \mathrm{sec}$.

Analysis of the real samples using the optimized method

Thirty-two samples of brandy, cognac, whisky and whiskey were analyzed (Table 2). The samples were collected in the period October, 2012 to
February, 2013 from local shops in Almaty and Almaty oblast. According to available information (color, packaging, smell, taste), part of the samples represented adulterated alcohol products.

SPME was carried out for $0.50 \mathrm{~min}$ at $30^{\circ} \mathrm{C}$. All samples were separately analyzed using 100 $\mu \mathrm{m}$ PDMS and DVB/CAR/PDMS fibers. To obtain the required sensitivity at low extraction time, mass spectrometric detection was performed in selected ion monitoring (SIM) mode according to the program which included 29 groups of ions (Table 3). The SIM program included all the compounds previously identified in all the studied samples of alcoholic beverages. Identification of peaks on the collected SIM chromatograms was conducted by retention times using confirmation ions. For each compound, the peak area was determined on extracted ion chromatogram by the most abundant ion. The data was then entered into MS Excel sheet and imported into SPSS Statistics (IBM) ver. 20 software for statistical processing of the results. The statistical processing was conducted by principal component analysis (PCA) using covariance matrices and Bartlett variables. Two most important variables were extracted and plotted.

Table 2 - Samples of alcoholic beveragesanalyzed by the developed method

\begin{tabular}{|c|c|c|c|}
\hline Sample ode & Name (manufacturer) [percentage of ethanol] & Type & Country \\
\hline 12 & Kazakhstan (Bacchus OJSC) [40\%] & Brandy & Kazakhstan \\
\hline 25 & Gold $[42 \%]$ & Brandy & Kazakhstan \\
\hline 27 & LE Graff (“BN" Liquor-vodka factory) [40\%] & Brandy & Kazakhstan \\
\hline 33 & Hot Irishman $[40 \%]$ & Whiskey & Ireland \\
\hline 37 & Remy Martin VS Super Rieur [40\%] & Cognac & France \\
\hline 40 & Marsel (Akros) [40\%] & Brandy & Kazakhstan \\
\hline 42 & Kazakhstan (Aliya LTD) [40\%] & Brandy & Kazakhstan \\
\hline 48 & Al-Farabi (WIMPEX) [42\%] & Brandy & Kazakhstan \\
\hline 51 & Scottish Collie $[40 \%]$ & Whisky & Scotland \\
\hline 52 & Seitek, 5 stars & Brandy & Kazakhstan \\
\hline 55 & Chinese $[38 \%]$ & Brandy & China \\
\hline 56 & Kazakhstan (Wine Master LTD) [40\%] & Brandy & Kazakhstan \\
\hline 59 & Gosudarev Zakaz ("BN" Liquor-vodka factory) [40\%] & Brandy & Kazakhstan \\
\hline 63 & Kazakhstan (Bacchus LLP) [40\%] & Brandy & Kazakhstan \\
\hline 64 & Chivas Regal (Pernod Ricard) [40\%]* & Whisky & Scotland \\
\hline 65 & Chivas Regal (Pernod Ricard) [40\%] & Whisky & Scotland \\
\hline
\end{tabular}


Continuation of table 2

\begin{tabular}{|c|c|c|c|}
\hline Sample ode & Name (manufacturer) [percentage of ethanol] & Type & Country \\
\hline 66 & Black Label (Johnnie Walker) [43\%] & Whisky & Scotland \\
\hline $67-72$ & Black Label (Johnnie Walker) [43\%] ${ }^{*}$ & Whisky & Scotland \\
\hline 73 & Black Label (Johnnie Walker) [43\%] & Whisky & Scotland \\
\hline 74 & Black Label (Johnnie Walker) [37.5\%] $*$ & Whisky & Scotland \\
\hline 75 & Jack Daniels [40\%] & Whisky & USA \\
\hline 76 & Jack Daniels $[40 \%]$ & Whisky & USA \\
\hline 77 & Gold Label (Johnnie Walker) [43\%] & Whisky & Scotland \\
\hline 78 & Hennessy V.S.O.P. Privilege Cognac [40\%] & Cognac & France \\
\hline 79 & Asanali (Bacchus OJSC) [40\%] & Brandy & Kazakhstan \\
\hline 80 & Meiram $[40 \%]$ & Brandy & Kazakhstan \\
\hline 81 & $\begin{array}{l}\text { Kazakhstan Very Special Old V.S.O.P. Exclusive ("BN" liquor- } \\
\text { vodka factory) }[40 \%]\end{array}$ & Brandy & Kazakhstan \\
\hline
\end{tabular}

Table 3 - Selected ion monitoring program for the analysis of samples of alcoholic beverages by SPME-GC-MS

\begin{tabular}{|c|c|c|c|c|}
\hline \multirow[b]{2}{*}{ \# } & \multirow{2}{*}{$\begin{array}{c}\text { Group } \\
\text { start time, } \\
\text { min }\end{array}$} & \multicolumn{2}{|c|}{ Ions (Dwell) } & \multirow[b]{2}{*}{ Detected compounds } \\
\hline & & $\begin{array}{l}\text { Quantification ions } \\
\text { (Dwell } 50 \mathrm{~ms} \text { ) }\end{array}$ & $\begin{array}{l}\text { Confirmation ions } \\
\text { (Dwell } 10 \mathrm{~ms} \text { ) }\end{array}$ & \\
\hline 1 & 2.2 & $41 ; 59 ; 60 ; 86 ; 88$ & $61 ; 74 ; 103$ & $\begin{array}{l}\text { acetic acid, ethyl acetate, 2-methyl-1-propanol, } \\
\text { diethoxymethane, 2-methyl butanal }\end{array}$ \\
\hline 2 & 3.4 & $55 ; 102 ; 116$ & $70 ; 88$ & ethyl propanoate, isoamyl alcohol, ethyl isobutyrate \\
\hline 3 & 5.2 & 55 & $41 ; 70$ & 1-butanol 3-methyl formate \\
\hline 4 & 5.6 & 88 & 60 & ethyl butanoate \\
\hline 5 & 6.6 & $45 ; 88 ; 102$ & $60 ; 74 ; 75$ & $\begin{array}{l}\text { ethyl 2-hydroxypropanoate, 2-methyl ethylbutanoate, ethyl- } \\
\text { 3-methylbutyrate }\end{array}$ \\
\hline 6 & 8.6 & $56 ; 70$ & $55 ; 87$ & 1-hexanol, 3-methylbutyl acetate \\
\hline 7 & 10.1 & 96 & 39 & furfural \\
\hline 8 & 15.9 & 88 & 99 & ethyl hexanoate \\
\hline 9 & 17.8 & 105 & 106 & benzaldehyde \\
\hline 10 & 20.3 & $45 ; 55 ; 69$ & $41 ; 56 ; 70 ; 87$ & $\begin{array}{l}\text { ethyl 2-hydroxy-4-methylpentanoate, 1-octanol, isoamyl } \\
\text { lactate }\end{array}$ \\
\hline 11 & 22.3 & 45 & 69 & 2-nonanol \\
\hline 12 & 25.6 & 105 & $77 ; 120$ & acetophenone \\
\hline 13 & 28.4 & $88 ; 91$ & $92 ; 101 ; 122 ; 127$ & phenylethyl alcohol, ethyl octanoate \\
\hline 14 & 30.4 & 60 & & octanoic acid \\
\hline 15 & 31.6 & $101 ; 105 ; 120$ & $92 ; 122 ; 129 ; 134$ & $\begin{array}{l}\text { 3-ethyl benzaldehyde, butanedioic acid ethyl ester, methyl } \\
\text { 2-hydroxy-benzoate }\end{array}$ \\
\hline 16 & 34.4 & 55 & 70 & decanol \\
\hline 17 & 37.7 & 104 & 91 & 2-phenyl acetate \\
\hline 18 & 41.9 & $70 ; 88$ & $55 ; 101$ & ethyl decanoate, ethyl 9-decenoate \\
\hline 19 & 43.8 & $57 ; 70$ & 127 & 5-ethyl-2-methyloctane, 3-methylbutyl octanoate \\
\hline 20 & 47.7 & 133 & 148 & 1-(2,5-dimethylphenyl)ethanone \\
\hline 21 & 50.3 & 155 & 56 & isobutyl decanoate \\
\hline 22 & 52.1 & $69 ; 88 ; 126$ & $93 ; 98 ; 101$ & ethyl dodecanoate \\
\hline 23 & 56.0 & 70 & 155 & 3-methylbutyl decanoate \\
\hline 24 & 60.2 & 69 & 81 & 3,7,11- trimethyl-6,10-dodecadien-1-ol \\
\hline 25 & 64.1 & 88 & 101 & ethyl tetradecanoate \\
\hline 26 & 65.8 & $70 ; 81$ & $55 ; 69$ & isoamyl laurate \\
\hline 27 & 68.5 & 69 & 93 & farnesol acetate \\
\hline 28 & 72.4 & $55 ; 88 ; 149$ & $69 ; 101 ; 150 ; 284$ & diisobuthyl phthalate, ethyl hexadecanoate \\
\hline 29 & 75.5 & 104 & 105 & nonyl 2-phenylethyl oxalate \\
\hline
\end{tabular}




\section{Data processing}

The data were processed using the SPSS Statistics (IBM) ver. 20 software. Principal component analysis (PCA) using covariance matrices and Bartlett variables were retrieved. Two first two component were extracted and plotted.

\section{Results and discussion}

\section{Optimization of extraction temperature}

Increase of extraction temperature from 30 to $70^{\circ} \mathrm{C}$ lead to the 3 -fold increase of the total peak area (Figure 2a) as the peak areas of the majority of the individual analytes due to the increase of their vapor pressures (Figure 2b). An increase of the extraction temperature from 30 to $70^{\circ} \mathrm{C}$ resulted in a 5-fold increase of the response of ethyl decanoate. On the other hand, a decrease in response was observed for some compounds as, e.g., ethyl acetate (Figure 2b), which can be explained by a decreasing distribution constant between the polymer fiber coating and the headspace.

Despite the observed increase of the analytes response, the results are hampered by higher signal relative standard deviations (RSDs) and several new non-reproducible peaks appearing in the chromatograms obtained at extraction temperatures over $40^{\circ} \mathrm{C}$. Such changes may be caused by unwanted side reactions running in the vials. Such reactions may occur between brandy constituents or with oxygen present in the headspace. Such fluctuations in the results obviously affect the reliability of the method in a negative way. A further problem associated with extraction at high temperatures is caused by a higher water response, especially when using DVB/CAR/PDMS fiber. This may negatively affect the lifetime of the MS detector filament and thus the overall detector sensitivity.

To be safe, the extraction temperature $30^{\circ} \mathrm{C}$ was selected as optimal. The selected temperature is close enough to room temperature to do extraction without autosampler. It significantly expands the applicability of the method in the practice of forensic examination.

\section{Optimization of extraction time}

The total peak area increases with increasing extraction time reaching a plateau after approx. $60 \mathrm{~min}$ (Figure 3). These results correspond to earlier findings [17]. However, the equilibrium in the system is not established even after $100 \mathrm{~min}$ of extraction (Figures 3-4). Thus, the responses of the heaviest compounds (ethyl tetradecanoate and ethyl hexadecanoate) increase linearly during the studied time period, which can be explained by their higher affinity to the coating and a lower volatility compared to other compounds. The response of the lightest of the studied compounds (ethyl hexanoate) increases during the first 10 min of extraction process followed by a gradual decrease (Figures 4-5).

It appears that the obtained data may be rationalized in terms of a displacement from the SPME fiber of the more volatile compounds by heavier compounds due to a limited capacity of the coating and higher adsorption affinity of the heavier compounds. Displacement of analytes from the fiber can potentially lead to problems with linearity of calibration plots and thus quantification, two factors that for forensic purposes appear crucial. For DVB/CAR/PDMS fiber, extraction time before displacement apparently is limited to $2 \mathrm{~min}$, whereas for PDMS fiber, this time range appears much wider (10 min). This fact can be explained by its absorptive nature (versus adsorptive nature of DVB/CAR/PDMS) and higher analyte capacity. During SPME by absorptive coatings, their whole volume is involved while adsorptive fibers provide only their surface area.

When selecting an optimal extraction time, the linear range of the detector plays a crucial role. In the present experimental set-up, linearity of the applied Agilent 5973N mass spectrometric detector under the optimized conditions is limited to the extraction time of $1 \mathrm{~min}$. For samples having higher concentrations of VOCs, linear range may be even narrower (less than $30 \mathrm{sec}$ ). Safe work at higher extraction times requires detector/filament switch off during elution of the most abundant peaks (esters and isoamyl alcohol).

Comparison of the data collected using the two different fiber coatings at different extraction times (Figures 4-5) disclosed that the DVB/CAR/PDMS fiber provides higher responses of less abundant peaks, which obviously may be crucial for their detection. There is no problem with the detection of most abundant peaks because they provide a high response. Despite better selectivity of the DVB/ CAR/PDMS fiber [16], higher sensitivity without unwanted displacement may be achieved using $100 \mu \mathrm{m}$ PDMS fiber. However, further studies are required eventually to select the optimal fiber coating.

\section{Optimization of salt addition}

An increase of salt concentration in the range of $0-1.25 \mathrm{~g}$ leads to an increase of total peak area (Figure 6a). The responses of the more polar compounds such as isoamyl alcohol continuously increase in the whole studied region (Figure 6b) 
whereas the peak areas of the most abundant compounds (ethyl octanoate and ethyl decanoate) increase with increasing $\mathrm{NaCl}$ mass from 0.75 to $1.25 \mathrm{~g}$ followed by a slight decrease. This decrease may be caused by a competition with an increased vapor pressure of ethanol, which is caused by an increased salt concentrations. As discussed above, such competition processes are not desirable. Thus, it is concluded that salt addition should be avoided.

\section{Analysis of the real samples}

The attempt to differentiate tested samples using principal component analysis (PCA) of the areas of all the peaks on the chromatogram as data set was made (Figure 7). It is immediately seen that samples 25 and 27 differ substantially from the other samples. The most intense peaks characteristic to the samples of cognac and brandy were missing in the chromatograms of these samples.
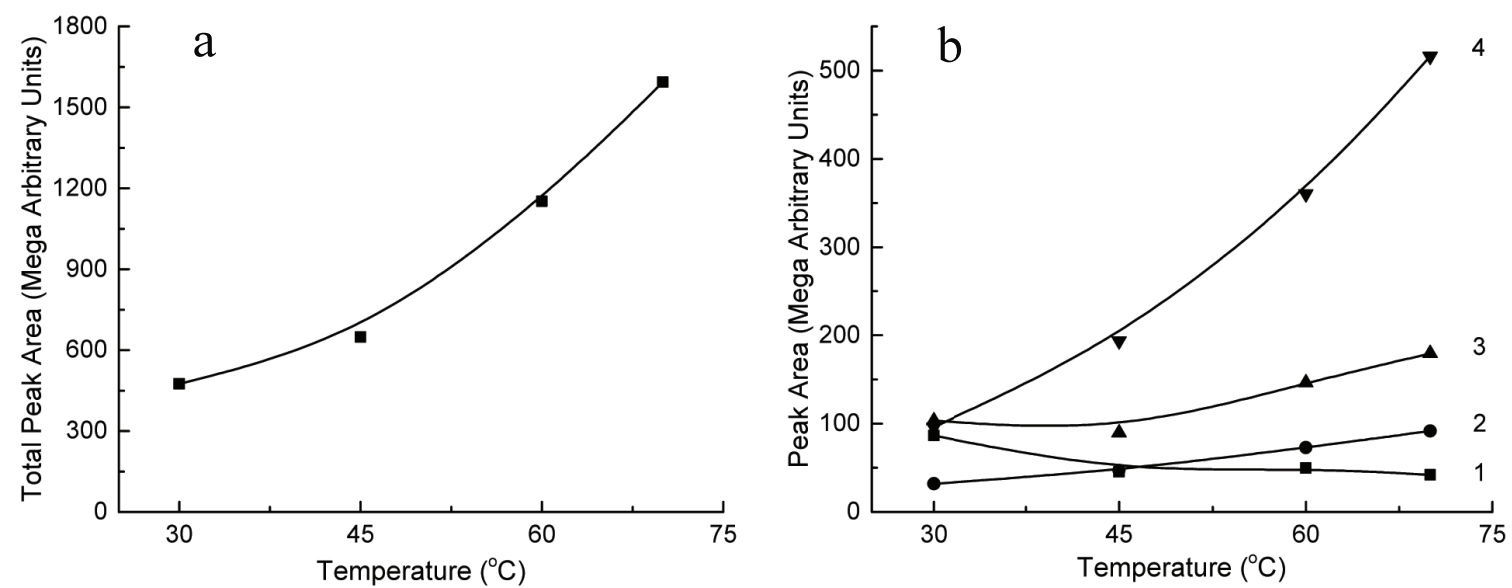

Figure 2 - Effect of the extraction temperature on the total peak area (a) and peak areas of individual brandy VOCs (b). Note: 1 -ethyl acetate 2 - ethyl hexanoate; 3 - isoamyl alcohol; 4 - ethyl decanoate
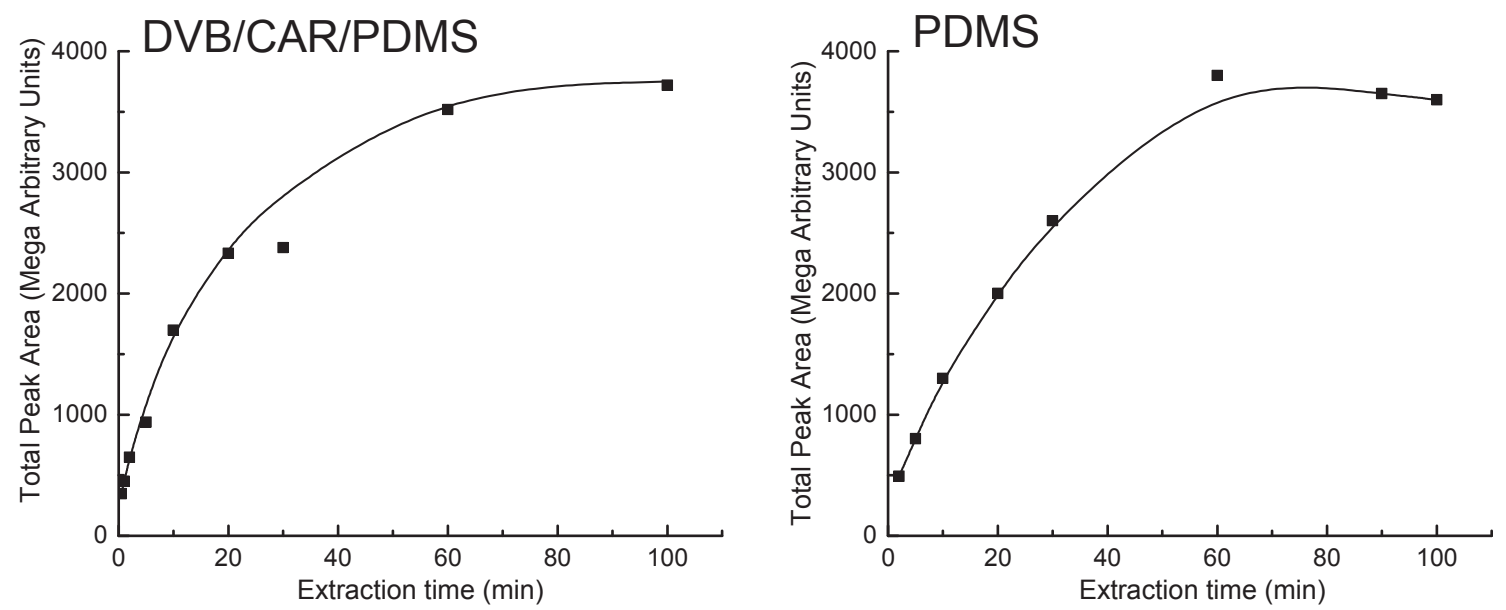

Figure 3 - Effect of extraction time on the total peak area of brandy VOCs by SPME-GC-MS using DVB/CAR/PDMS and 100 um PDMS fiber coatings

The resulting diagrams allowed differentiating samples of cognac and whisky - cognac samples were mostly on the left side of the diagram while whisky samples were on the right. Potentially adulterated whisky samples (\#64 and \#67-72) were well differentiated from the original products (\#65 and \#66) in the PCA plots. Whiskey sample \#33 was very close to the other adulterated samples on the both PCA plots. This sample can be classified as potentially adulterated. However, it should be 
noted that whereas the original whisky samples (\#65 and \#66) are of Scotch original sample \#33 is an Irish whiskey. Differentiation of Scotch and Irish products will require access to further samples. The potentially expected adulterated whisky sample $(\# 74)$ is very far from the original one (\#73) in the PCA map, it is much closer to the group of adulterated samples. It is in this connection also worthwhile to mention that the two samples of American whiskey (\#75 and \#76), which apparently should be identical are located far away from each other in the PCA map (Figure 6a), which could suggest that these samples should be subjected to further investigation. Thus, the final conclusion can be done by a detailed comparison to the proven original samples.

The PCA plots obtained based on the data collected using two different fibers appear relatively similar. However, DVB/CAR/PDMS provided slightly higher differentiation efficiency of adulterated and original whisky samples. In most cases, DVB/CAR/PDMS fiber allowed detection of a higher number of target compounds compared to the PDMS fiber (Figure 8). Extraction selectivity of the DVB/CAR/PDMS coating to higher numbers of compounds can be explained by its multicomponent chemical composition and higher selectivity to polar compounds mostly present in alcoholic samples.
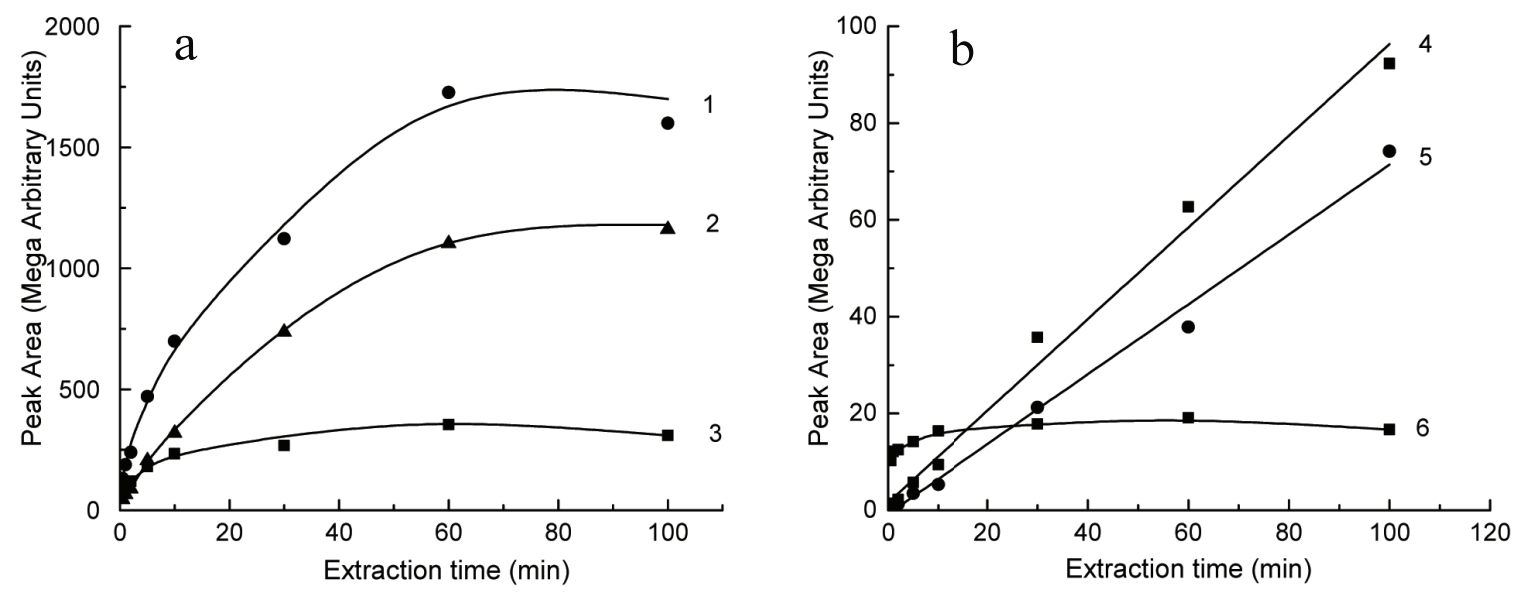

Figure 4 - Peak areas of selected compounds at different extraction times using $100 \mu \mathrm{m}$ PDMS coating. Note: 1 - ethyl decanoate; 2 - ethyl dodecanoate; 3 - ethyl octanoate; 4 - ethyl tetradecanoate; 5 - ethyl hexadecanoate; 6 - ethyl hexanoate
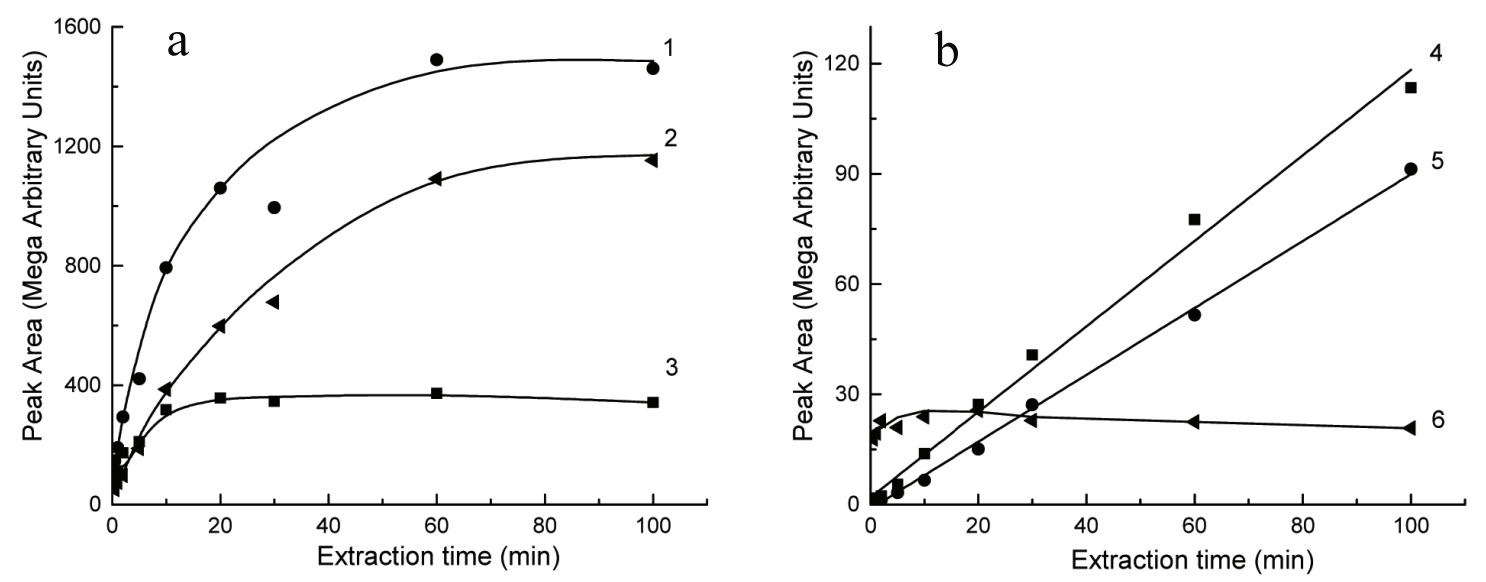

Figure 5 - Peak areas of selected compounds at different extraction times using DVB/CAR/PDMS coating. Note: 1 - ethyl decanoate; 2 - ethyl dodecanoate; 3 - ethyl octanoate; 4 - ethyl tetradecanoate; 5 - ethyl hexadecanoate; 6 - ethyl hexanoate 

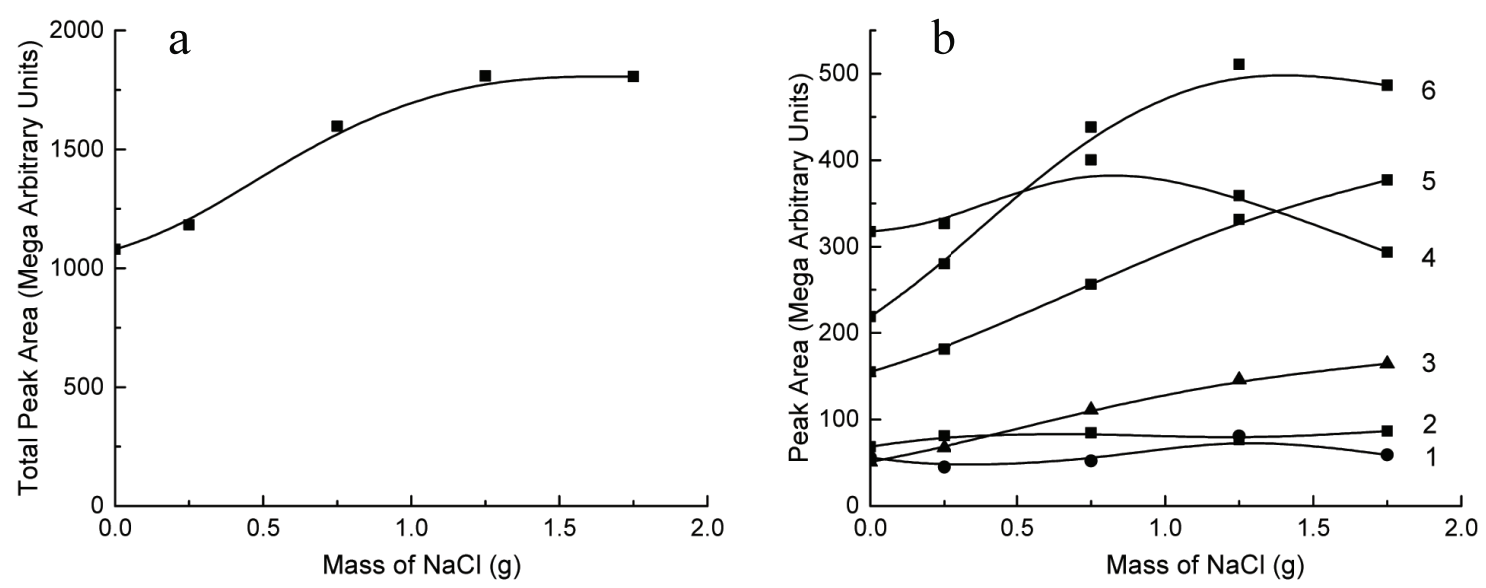

Figure 6 - Effect of the amount of salt additive to cognac sample on the extraction efficiency of certain compounds. Note: 1 - furfural (x10); 2 - ethyl acetate; 3 - ethyl hexanoate; 4 - ethyl decanoate; 5 - isoamyl alcohol; 6 - ethyl octanoate; x10 - peak area multiplied by $10 ; \mathrm{M}$ a.u. - Mega arbitrary units. Fiber coating DVB/CAR/PDMS, extraction temperature 30C, extraction time $30 \mathrm{sec}$, pre-incubation time $15 \mathrm{~min}$, sample volume $6 \mathrm{~mL}$, vial volume $20 \mathrm{~mL}$.
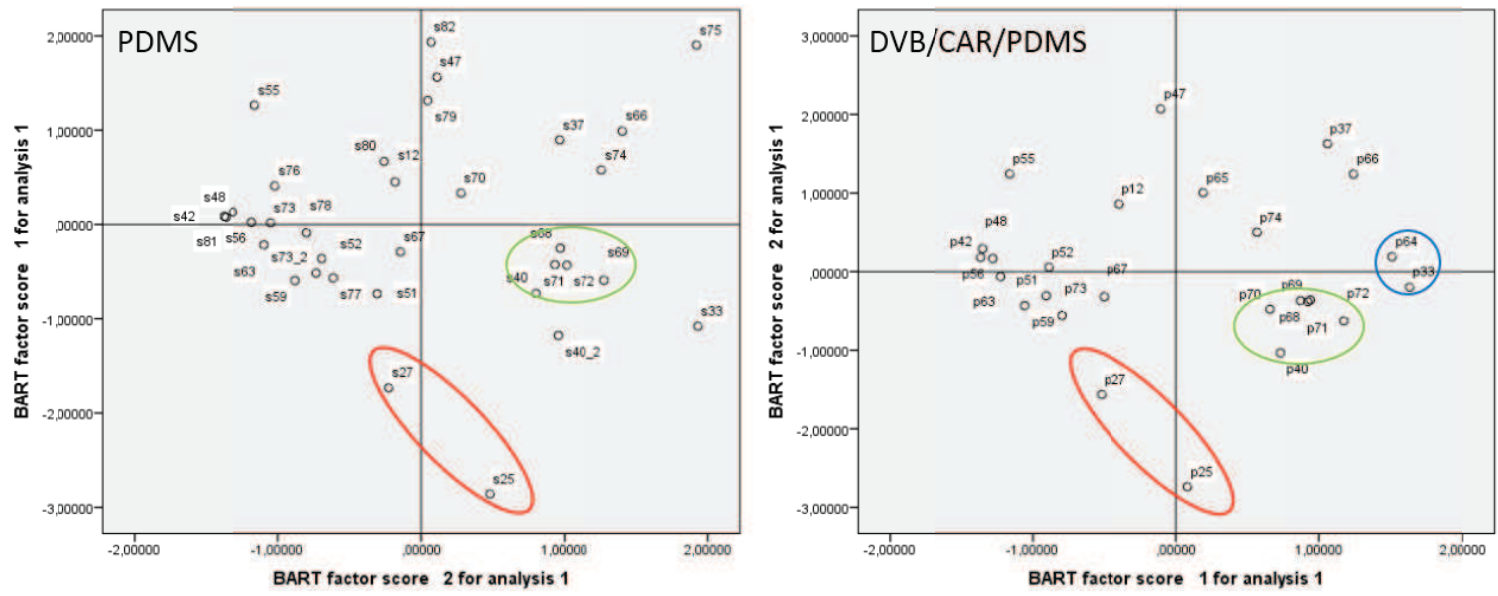

Figure 7 - Statistical distribution diagram taking into account peak area of all compounds (96.97\% variance for PDMS (a) and $97.45 \%$ variance for DVB/CAR/PDMS (b)). Note: samples of surrogate cognacs and whiskies are encircled by ellipses with colored contours

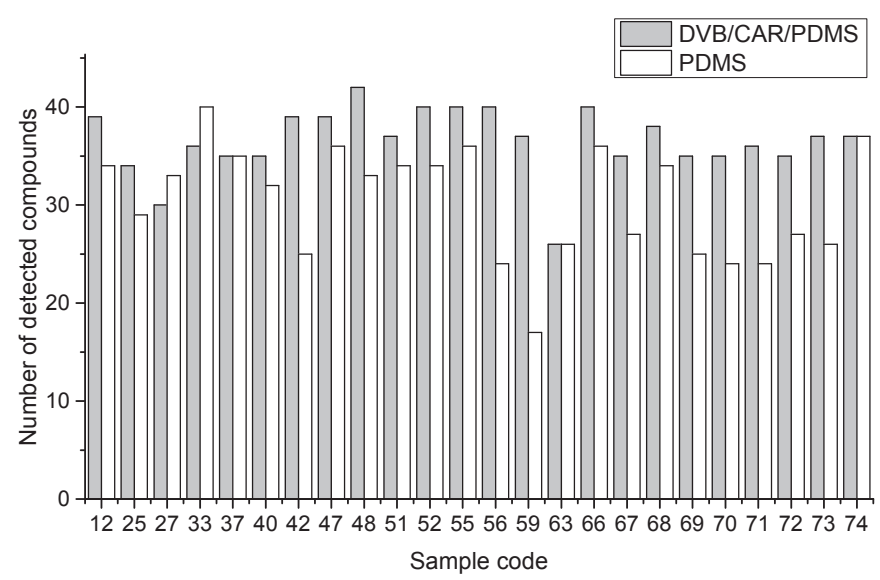

Figure 8 - Number of compounds detected in each sample using studied extraction coatings

ҚазҰУ хабаршысы. Химия сериясы. №4 (76) 2014 
ThePCA plots obtained basedon the data collected usingtwo different fibers appear relatively similar. However, DVB/CAR/PDMS provided slightly higher differentiation efficiency of adulterated and original whisky samples. In most cases, DVB/CAR/PDMS fiber allowed detectionof a higher number of target compounds compared to the PDMS fiber (Figure 8). Extraction selectivity of the DVB/CAR/PDMS coating to higher numbers of compounds can be explained by its multicomponent chemical composition and higher selectivity to polar compounds mostly present in alcoholic samples.

\section{Conclusion}

New SPME-GC-MS method for discovery of adulterated alcoholic beverages has been developed. The method parameters were experimentally optimized to provide high precision and reliability. According to the experiments, increase of extraction temperature leads to the increase in response of the most VOCs. However, to avoid transformation/ degradation of the samples, the extraction temperature must be limited to $30^{\circ} \mathrm{C}$ (or to the minimum temperature of the autosampler). Increase of the extraction time to 60 min leads to the increase of total peak area. However, longer extraction times ( $>10$ min for PDMS and $>2$ min for DVB/ CAR/PDMS) caused an undesired displacement of analytes on the SPME fiber. For mass spectrometric detector, the extraction time should be limited to 1 min while flame ionization detector may be used if longer extraction times appear necessary. Increase of $\mathrm{NaCl}$ mass up to $1.7 \mathrm{~g}$ added to the extracted sample leads to the increase of total peak area. However, the salt addition promotes competition between ethanol and the analytes for adsorption sites and causes problems with reproducibility. Therefore, it is concluded that an addition of salt prior to extraction is undesirable for the here presented method.

The developed method was successfully applied for discovery of adulterated samples of brandy and whisky. Principal component analysis plots obtained using the data collected by both $100 \mu \mathrm{m}$ PDMS and DVB/ CAR/PDMS coatings were virtually similar. However, the DVB/CAR/PDMS fiber appears more efficient for detection of adulteration markers. Adulteration of potentially adulterated brandy and whisky samples was confirmed. One whiskey sample was regarded as potentially adulterated one, but the geographic origin may play a role in this context. Further two potentially identical samples appeared at significant different locations in the PCA map. The developed method is recommended for application in forensic laboratories.

\section{Acknowledgement}

This work was conducted under International Science and Technology (ISTC) project K-1983 "Improvement of forensic methodology for discovery of adulterated alcoholic beverages" funded by the US Department of State.

\section{References}

1 Yoki.ru News (2013) Czech police confiscated more than one million liters of illegal alcohol [Cheshskaya policiya konfiskovala bolle milliona litrov nelegalnogo alkogolya]. http://www.yoki.ru/news/news/24-05-2013/403018-illegal-0/ (Accessed 05/05/2014, In Russian)

2 BBC News (2012) Czechs partially lift spirits ban after mass poisoning. http://www.bbc.com/news/world-europe-19738765 (Accessed 05/05/2014)

3 (2001) GOST R 51786-2001. Vodka and ethanol originated from food raw material. Gas chromatographic method for determination of authenticity [Vodka i spirt etilovyiy iz pischevogo syrya. Gazohromatograficheskiy metod opredeleniya podlinnosti]. Izdatelstvo Standartov, Moscow, Russia. (In Russian)

4 (2001) GOST R 51698-2000. Vodka and ethanol originated from food raw material. Express gas chromatographic method for determination of toxic microimpurities [Vodka i spirt etilovyiy iz pischevogo syrya. Gazohromatograficheskiy ekspress-metod opredeleniya soderzhaniya toksichnyih mikroprimesey]. Izdatelstvo Standartov, Moscow, Russia. (In Russian)

5 García-Falcón MS, Simal-Gándara J (2005) Food Addit Contam 22:791-797. http://dx.doi.org/10.1080/02652030500198498

6 Schwarz M, Rodríguez MC, Guillén DA, Barroso CG (2009) J Sep Sci 32:1782-1790. http://dx.doi.org/10.1002/ jssc. 200800706

7 Lachenmeier DW (2007) Food Chem 101:825-832. http://dx.doi.org/10.1016/j.foodchem.2005.12.032

8 Pontes MJC, Santos SRB, Araujo MCU, Almeida LF, Lima RAC, Gaiao EN, Souto UTCP (2006) Food Res Int 39:182-189. http://dx.doi.org/10.1016/j.foodres.2005.07.005

9 Ogrinc N, Kosir IJ, Spangenberg JE, Kidric J (2003) Anal Bioanal Chem 376:424-430. http://dx.doi.org/10.1007/s00216003-1804-6

10 Savchuk SA, Kolesov GM (2005) J Anal Chem+ 60:752-771. http://dx.doi.org/10.1007/s10809-005-0176-9

11 Dall'Asta C, Cirlini M, Morini E, Galaverna G (2011) J Chromatogr A 42:7557-7565. http://dx.doi.org/10.1016/j.chroma.2011.08.042 
12 Fitzgerald G, James KJ, MacNamara K, Stack MA (2000) J Chromatogr A 896:351-359. http://dx.doi.org/10.1016/S00219673(00)00737-8

13 Pino JA (2007) Food Chem 104:421-428. http://dx.doi.org/10.1016/j.foodchem.2006.09.031

14 Camara JS, Marques JC, Perestrelo RM, Rodrigues F, Oliveira L, Andrade P, Caldeira M (2007) J Chromatogr A 1150:198207. http://dx.doi.org/10.1016/j.chroma.2006.09.014

15 Cardeal ZL, Marriott PJ (2009) Food Chem 112:747-755. http://dx.doi.org/10.1016/j.foodchem.2008.06.057

16 Rodrigues F, Caldeira M, Camara JS (2008) Anal Chim Acta 609:82-104. http://dx.doi.org/10.1016/j.aca.2007.12.041

17 Plutowska B, Wardencki W (2008) Anal Chim Acta 613:64-73. http://dx.doi.org/10.1016/j.aca.2007.12.041

18 Bacchus OJSC (2014) Three-stars ordinary cognac “Kazakhstan”. http://bacchus.kz/en/catalog/cognac/ordinary/58-konyaktri-zvezdochki.html (Accessed on 05/05/2014, In Russian)

19 Cognac.fr (2014) Cognac. Controlled appellation of origin. http://www.cognac.fr/cognac/_en/2_cognac/index. aspx?page=appellation (Accessed on 15/05/2014) 